\title{
Results of studying wild relatives of the cultivated plants of Russia
}

\section{Irena Chukhina, Liliya Shipilina, Larisa Bagmet, Galina Talovina, and Tamara Smekalova ${ }^{\dagger}$}

Federal Research Center N. I. Vavilov All-Russian Institute of Plant Genetic Resources, Bol'shaya Morskaya ul., 42-44, Saint Petersburg, 190000, Russian Federation

Address correspondence and requests for materials to Irena Chukhina, irena_wir@mail.ru
Citation: Chukhina, I., Shipilina, L., Bagmet, L., Talovina, G., and Smekalova, T. ${ }^{\dagger}$ 2020. Results of studying wild relatives of the cultivated plants of Russia. Bio. Comm. 65(1): 41-52. https://doi. org/10.21638/spbu03.2020.104

Author's information: Irena Chukhina, $\mathrm{PhD}$, Leading Researcher, orcid.org/00000003-3587-6064; Liliya Shipilina, PhD Senior Researcher, orcid.org/0000-00017590-3173; Larisa Bagmet, PhD, Leading Researcher, orcid.org/0000-0003-0768-0056; Galina Talovina, PhD, Senior Researcher, orcid.org/0000-0001-6167-1455; Tamara Smekalova, PhD, Leading Researcher, orcid. org/0000-0002-0618-1506

Manuscript Editor: Anton Nizhnikov, Department of Genetics and Biotechnology, Faculty of Biology, Saint Petersburg State University, Saint Petersburg, Russia

Received: September 30, 2019;

Revised: November 13, 2019;

Accepted: November 22, 2019;

Copyright: (c) 2020 Chukhina et al. This is an open-access article distributed under the terms of the License Agreement with Saint Petersburg State University, which permits to the authors unrestricted distribution, and self-archiving free of charge.

Funding: This study is supported by VIR project No 0662-2019-0005.

Competing interests: The authors have declared that no competing interests exist.

\begin{abstract}
Issuing specific recommendations on the in situ conservation of wild relatives of cultivated plants (=crop wild relatives, CWR) in Russia is possible only on the basis of preliminary comprehensive studies of their composition, structure and features. N. I. Vavilov was the founder of comprehensive studies of cultivated plant relatives. O. N. Korovina was the first to substantiate the basic principles of conserving CWR diversity in their natural habitats, and to suggest choosing the most suitable conservation measures, taking into account the data on the distribution area of a taxon, the state of habitat condition, the state of the taxon in nature, and human influence. The current phase of studying CWR diversity and developing a domestic strategy for its conservation is associated with geopolitical changes in this country, and with the inclusion of research performed at VIR on CWR diversity in situ conservation into large-scale international projects. The fundamental conditions for attributing a wild species to relatives of cultivated plants are, first, taxonomic or evolutionary and genetic closeness to a cultivated species, and second, the use of species in breeding, or the potential introduction of a species into cultivation. The work on the compendium of wild relatives of cultivated plants of Russia is still far from completion. As a result of the inventory, a list of 1701 species of relatives of cultivated plants for food and agriculture was compiled. The largest number of species (965) grows in the European part of Russia. The Russian Caucasus ranks second in terms of CWR richness (956 species), and the third in CWR numbers is the Russian Far East (598 species). The 102 nature reserves included in the study contain 1363 CWR species. The CWR diversity is most effectively conserved in the nature reserve network of the Russian Far East and Eastern Siberia, and least of all in the nature reserves of the Russian Caucasus, despite the significant concentration of CWR species in this region.
\end{abstract}

Keywords: wild relatives of cultivated plants, crop wild relatives (CWR) of Russia, plant genetic resources (PGR), in situ conservation, Red Books, specially protected natural areas (SPNA).

\section{Introduction}

In recent decades, international experts have been more frequently making upsetting forecasts about unfavorable climate changes leading to reduced yields, on the one hand, (Porter et al., 2014), and about the growing global population, on the other hand (United Nations, 2019; World Development Report, 2008; Godfray et al., 2010). At the same time, there continues the loss of diversity of plant genetic resources suitable for food and agriculture, degradation of the environment and reduction of land and water resources, as well as a significant decrease in the ability of future generations to adapt to climate change, ensure food security and economic development on Earth (FAO, 2011). The changing climate, growing urbanization, the need for higher agricultural sustainability, and the need to preserve plant genetic diversity and minimize genetic erosion - all of this requires 
increased attention to the conservation and use of plant genetic resources for food and agriculture (FAO, 2011). In this regard, the interest in studying the genetic diversity of wild relatives of cultivated plants (=crop wild relatives, CWR) keeps growing. CWR are wild-growing species that have different degrees of relationship to cultivated plants of varying socio-economic significance as food for humans, or feeds for animals, as medicinal and industrial raw matter, as well as ornamental crops. Like cultivated plants, they are an integral part of plant genetic resources (PGR). CWR demonstrate a high level of genetic diversity and potentially possess a number of traits that can be used in breeding programs to increase resistance of modern plant varieties to pathogens and abiotic stresses, and to increase their yields as a result.

Though the recent decades (late $20^{\text {th }}-$ early $21^{\text {st }}$ centuries) witnessed the adoption of the Convention on Biological Diversity (CBD, 1992) and a number of international agreements and treaties, such as the Global Plan of Action for the Conservation and Sustainable Use of Plant Genetic Resources for Food and Agriculture (1996), the European Strategy for Plant Conservation (2001), the Global Strategy for Plant Conservation (2002), the International Treaty on Plant Genetic Resources for Food and Agriculture (2001), the Second Global Plant Genetic Resources Action Plan for Food and Agriculture (2011), still the problem of conserving genetic diversity of wild relatives of cultivated plants in most countries of the world, as well as in Russia, remains an urgent one.

\section{The history of the development in Russia of the scientific foundations for the study and conservation of the diversity of wild relatives of cultivated plants}

The first steps towards understanding the diversity of domestic cultivated plants and their wild relatives were made by a pleiad of talented Russian researchers who laid the foundation of the Bureau for Applied Botany (at present, the N. I. Vavilov All-Russian Institute of Plant Genetic Resources (VIR)). In the times of Robert E. Regel, employees of the Bureau began to explore the territory of Russia, collect and study local varieties and useful wild plants for applied purposes. Systematic large-scale studies of the global wealth of cultivated plants and their relatives were continued by the fundamental works of N. I. Vavilov $(1926,1931)$ and his contemporaries E. N. Sinskaya (1928, 1969), P.M.Zhukovsky (1964, 1968, 1970), M.G. Popov (1928-1929) and others. Since the attention of researchers was focused at that time on revealing the origin of the global diversity of cultivated plants, the studies were first of all concentrated on their closest relatives, which either directly gave rise to one or another crop, or participated in their origin. In his works, N. I. Vavilov did not give a special definition of the wild relatives of cultivated plants, but repeatedly used this term. From a brief comment given by N. I. Vavilov regarding Hordeum spontaneum (1926), it can be concluded that he regarded wild species related to cultivated plants as the relatives of the latter, while distinguishing the immediate ancestors. N.I. Vavilov was the founder of a comprehensive study of relatives of cultivated plants (1931). He strongly recommended inventorying the vast range of the forms of wild relatives found in nature and harnessing their gene pools in order to improve cultivated forms and to create new varieties. According to N.I.Vavilov, the study of wild relatives was the basis for the in-depth cognition of the evolution of cultivated plants. When analyzing the wild relatives of fruit trees in the Asian part of the USSR and the Caucasus, Nikolai Vavilov drew attention to the fact that a study of wild relatives should be carried out using the method of "differential systematics", and it is necessary to determine the "diversity within the Linnaean species", a "system" of species, and also to identify "geographical locations of species' components". N. I. Vavilov noted the laboriousness of such work, which required "collecting many thousands of samples of one and the same species", both living forms, and a "complete herbarium" (Vavilov, 1931).

Later on, P.M.Zhukovsky developed the ideas of N. I. Vavilov on the role of wild relatives in improving the existing diversity of cultivated plants, as well as in studying their origin, and published the monograph Cultivated Plants and Their Relatives (1964) which was reprinted many times. He deepened the study of the centers of origin of cultivated plants, introduced the concept of "microcenters" of wild-growing species - the congeners (in the author's edition) of cultivated plants - and gave an overview of these narrowly endemic microcenters with a list of 102 species belonging to them (Zhukovsky, 1968, 1970).

In 1975, V.V.Nikitin and O. N. Bondarenko (Korovina) published a summary of wild relatives ("congeners" in the authors' edition) of cultivated plants entitled Wild Relatives of Cultivated Plants and Their Distribution in the USSR, which included 613 species growing in the Soviet Union. This work became the starting point of a new stage in the inventory and study of CWR in order to enrich the initial material of cultivated plants with valuable germplasm, to familiarize breeders with wild relatives of cultivated plants growing within the USSR, as well as to protect them in natural habitats as a valuable genetic source. The wild relatives (congeners) were understood by the authors as the "species that spontaneously or with human assistance took part in the formation of cultivated plant varieties" (p. 3, Nikitin and Bondarenko, 1975). Their compendium included only those types of CWR that deserved breeders' attention.

Over the next decade, O.N. Korovina continued the inventory of CWR diversity in the Soviet Union. In collaboration with D.D. Brezhnev, they published the monograph Wild Relatives of Cultivated Plants of the USSR 
(1981), in which they gave a brief description of more than 600 most important wild "congeners" of the cultivated plants growing in the USSR. It is especially important that this work provides characteristics of not only CWR species, but of subspecies as well. Almost a quarter of the described taxa are endemics (100) or species that rarely occur in this territory (60). Besides, the book indicated the species growing in nature reserves that were listed or proposed for inclusion in the Red Book of the USSR.

Later on, in the annotated list The Natural Genetic Diversity of Wild Relatives of Cultivated Plants in the Flora of the USSR and its Protection (1986), O. N. Korovina specified the notion of wild relatives of cultivated plants as of the "species of natural flora that are evolutionarily and genetically close to cultivated plants; the species utilized by humans for the introduction, use in cultivation, as well as in crosses in order to obtain more advanced varieties." This publication provided a list of as many as 763 species of wild relatives that occur in the former USSR, of which 455 were growing in the Russian Federation. The author's comparative analysis of the distribution of CWR species between the regions of the USSR showed that the greatest variety of relatives of cultivated plants grows in the Caucasus.

It was Olga N.Korovina who developed and substantiated for the first time the basic principles of CWR diversity preservation (Nikitin and Bondarenko (Korovina), 1973; Korovina, 1980a, 1980b, 1986). When studying relatives of cultivated plants within the Central Asian genetic center, she offered an original classification using the notion of the "form of existence" (Korovina, 1984), according to which CWR were subdivided into:

only wild-growing,

wild-growing and weedy,

wild-growing and cultivated at the same time,

wild-growing, cultivated and feral,

wild-growing, cultivated and weedy,

wild-growing, cultivated, weedy and feral,

feral and cultivated,

weedy and cultivated,

weedy, cultivated and feral, and weedy.

Although the proposed notion of the "form of existence of the wild relatives of cultivated plants" was not entirely successful, the principle itself is very relevant. Such an approach to the analysis of regional CWR diversity allows one to distinguish the indigenous and adventive plant groups that make up the overall diversity, and to understand the functional role of CWR and the ways of CWR diversity formation. O.N. Korovina paid great attention to preserving the diversity of wild relatives of cultivated plants in their natural habitats and suggested choosing the most suitable conservation measures, taking into account the data on the distribution area of a taxon, the state of habitat condition, the state of the taxon in nature, and human influence. In her opinion, it is necessary to preserve not only the narrowly local species, but also individual populations of the widespread species, as well as to use different types of protection involving the Red Book of the USSR and conservation in nature reserves, protected areas, botanical gardens, at experiment stations, and in genebanks. Thus, O.N. Korovina was the first in this country to propose conservation of CWR diversity both in situ and ex situ. Such an approach to CWR diversity conservation currently exists as a complementary ex situ/in situ conservation strategy (Maxted et al., 1997, 2000; Smekalova, 2011). O. N. Korovina developed a number of specific practical measures for the conservation of CWR species, which included:

- inventory and identification of the places with the highest concentration of CWR species, especially in the Vavilov centers of origin of cultivated plants;

- identification and inventory of populations of rare, endemic and relict CWR taxa, whose distribution area or the number of individuals in the distribution area are decreasing under the influence of various factors (in pursuit of the aim of declaring these populations natural monuments);

- making village councils and other organizations responsible for the preservation of populations of rare, endemic and relict CWR taxa identified in rural areas;

- CWR inventory in nature reserves and organization of studies of their biological peculiarities, including mapping, determination of abundance and living status, as well as identification of the factors that threaten safety of the species (Korovina, 1986).

Decades later, the recommendations and ideas of Olga N. Korovina would be mastered and developed by her followers in this country, as well as independently formulated and proposed by foreign scientists (Maxted et al., 2012).

The current stage of CWR diversity studies and development of a national strategy for its preservation is associated with geopolitical changes (the collapse of the USSR, the transformation of the Russian Federation and Union republics into independent states) and the inclusion of the research carried out by VIR on the in situ conservation of the CWR diversity into large international projects (ECPGR).

\section{European experience of developing a unified action plan for CWR in situ conservation}

The creation of a unified theoretical and methodological base for the conservation of plant genetic resources in Europe began about 30 years ago when the European 
Cooperative Programme for Plant Genetic Resources (ECPGR) was started in 1980. It was created following recommendations from the United Nations Development Program (UNDP), the Food and Agriculture Organization of the United Nations (FAO) and the Genebank Committee of the European Association for Research on Plant Breeding (EUCARPIA).

ECPGR is a joint program uniting most European countries. It aims to assist national, subregional and regional programs in Europe to rationally and effectively conserve plant genetic resources for food and agriculture ex situ and in situ, as well as to enhance their use. This program issues recommendations on the development of national strategies for CWR and landrace diversity conservation. Particular emphasis is placed on such aspects as:

(a) creation of national inventories;

(b) establishment of priorities for active conservation;

(c) comparison of taxonomic, ecogeographic, genetic data and of the existing threats;

(d) in situ and ex situ gap analysis;

(f) development of recommendations for complementary in situ and ex situ conservation.

N. Maxted proposed the most universal model for the conservation of genetic diversity of crop wild relatives (Maxted et al., 1997). This particular model was finalized in collaboration with representatives of European countries, including Russia, in the framework of ECPGR (Maxted et al., 2008, 2009, 2012, 2013). It is used in many countries for developing national programs for the conservation of CWR and plant genetic resources in general.

\section{Methodological approaches to CWR in situ conservation in Russia}

In recent decades, the staff of the N.I. Vavilov AllRussian Institute of Plant Genetic Resources (VIR) has been conducting systematic studies of CWR diversity with the aim of developing a unified national program for its in situ conservation, which would take into account the natural and economic features of Russia (Chukhina, 2001; Smekalova, 2008; Smekalova, 2011; Smekalova and Chukhina, 2005, 2011; Nukhimovskaya et al., 2005; Chukhina, 2007; Shipilina, 2016, 2017, 2018, 2019; Talovina and Aistova, 2017, 2018, 2019; Bagmet and Taysumov, 2018). When developing the main strategic approaches to the in situ conservation of CWR genetic diversity in Russia, the nearly 100 -year experience in studying the global diversity of cultivated plants and their wild relatives, as well as the accumulated international experience, were taken into account. The proposed strategy consists of the following interconnected blocks:
- inventory of CWR diversity in Russia;

- selection of objects (taxa or populations) of priority for conservation;

- selection of territories for in situ conservation;

- development of monitoring and management recommendations for various in situ conservation facilities.

All studies related to CWR in situ conservation should be carried out in several mutually intersecting domains, i.e. floristic - for studying CWR species diversity in regional floras and identifying within them priority species for conservation; taxonomic - for studying the genetic diversity of individual taxa (species, genera, etc.) by different methods (eco-geographical, morphological, anatomical, phylogenetic, biomolecular), identifying priorities for the conservation of species within their distribution areas; geographic - for identifying places where the greatest CWR species diversity is concentrated; populational - for studying inter- and intra-population variability of individual species, identifying populations with a unique set of genes or alleles, as well as populations containing the highest percentage of alleles. Thus, all in situ conservation objects can be represented at three levels, namely supraspecific (individual communities, local floras, etc.), specific (individual species throughout the entire distribution area), and populational (individual unique populations) (Chukhina, 2007).

\section{An inventory of CWR diversity in Russia}

The first step in any conservation effort is the performance of an inventory of plant diversity. Initially, it is necessary to decide what the notion of "wild relatives of cultivated plants" implies. Many researchers share the opinion that the fundamental conditions for attributing a wild species to relatives of cultivated plants are, first, taxonomic or evolutionary genetic closeness to a cultivated species, and second, the use of a species in breeding, or the potential introduction of a species into cultivation (Korovina, 1986; Smekalova and Chukhina, 2005, 2011; Maxted et al., 2006; Conserving Plant ..., 2008). Wild relatives of cultivated plants are population-species systems of wild plants which have an obvious evolutionary and genetic relationship with cultivated plants. A wild species can also be regarded as a wild relative in the absence of cultivated species in the corresponding genus if that species participated in the origin or evolution of particular cultivated species from other generic complexes.

The closeness of relationship between a cultivated species and its wild relatives can be estimated from the perspective of the concept of gene pools (Harlan et Wet, 1971), or the concept of taxonomic groups (Maxted et 
al., 2006). The use of the gene pool concept is acceptable in cases when the participation of genes of wild species in the gene pool of varieties is obvious and the gene pool can be easily determined. An approach based on the taxonomic hierarchy is more accessible for practical purposes. N. Maxted proposed the concept of taxonomic groups and identified four of them according to the taxonomic relationship: $1-$ crop and same species as crop; 2 - same series or section as crop; 3 - same subgenus as crop; 4 - same genus; 5 - same tribe but different genus to crop (Maxted et al., 2006).

When inventorying CWR diversity in Russia, we also adhered to the principle of systematic (taxonomic) closeness of wild species to cultivated plants. The species of natural flora that were evolutionarily and genetically close to cultivated plants and belonged to the same genus (Smekalova and Chukhina, 2005) were attributed to CWR. The priority at the current stage of inventory were wild relatives of cultivated plants that were used in domestic agriculture. First of all, these are the crops that ensure food security for people (cereals, vegetables, fruits, berries, etc.) and animal feeds (range and forage crops, etc.). Secondly, these are industrial crops, which serve as sources of vegetable oil, fiber, rubber, etc. At this stage, CWR of forest, medicinal and ornamental crops were not taken into account.

The first difficulty that we encountered at the beginning of our work on compiling a compendium of wild relatives of cultivated plants in Russia was the incompleteness of the inventory of domestic flora. Currently, there is no published Flora of Russia that would be similar to the once-published multi-volume monographic Flora of the USSR. According to different authors, the flora of Russia totals from 11,911 to 12,500 species and subspecies (Geltman et al., 1998; Kamelin, 2002).

As a result of a reconnaissance inventory of the entire CWR species diversity of Russia, a preliminary list was compiled to include 1680 species belonging to 48 families and 170 genera (Smekalova and Chukhina, 2005). In addition to the scientific name, each species was supplied with the information on the degree of relationship with cultivated plants and the involvement of its gene pool in breeding; on the distribution across Russia within five large geographic regions (i.e., European Russia, the Russian Caucasus, Western Siberia, Eastern Siberia, and the Far East); on the nature of use (food, forage, industrial, medicinal, ornamental); on the protection status, namely, the inclusion of a species in the Red List of the International Union for Conservation of Nature (IUCN) and in the Red Book of the Russian Federation (the Red Book of Russia, 2008, had not yet been published at that time).

The work on the compendium of CWR of Russia is still far from completion. Ideally, it should provide not only a list of taxa, but also information on the distribu- tion area, ecological features, economic importance and prospects of use, as well as possible and real threats to diversity. Numerous published floristic descriptions and keys to the floras of individual regions and administrative units of Russia, as well as the latest large floristic reports like the Flora of Siberia (1987-2003), Flora of Eastern Europe (1974-2004), Vascular Plants of the Soviet Far East (1985-1996), Flora of the Central Belt of the European part of Russia (Mayevsky, 2014), Compendium of Siberian Flora (2005), and the Compendium of the Flora of Asian Russia (Malyshev et al., 2012). To clarify the taxonomic composition, we used materials from the largest herbarium collections of the V.L. Komarov Botanical Institute (LE), Moscow State University (MW), Central Siberian Botanical Garden (NSK), Tomsk State University (TK), Institute of Biology and Soil Science of the Far East Branch of the Russian Academy of Sciences (VBGI), N. I. Vavilov All-Russian Institute of Plant Genetic Resources (WIR), as well as the results of personal field surveys. The creation of the compendium is preceded by a thorough analysis of the species' nomenclature and taxonomy, when the scope, structure, priority name and synonymy are verified. For verification of nomenclature combinations, international databases like International Plant Names Index (IPNI https://www. ipni.org/), Plant List (http://www.theplantlist.org/), Euro+Med PlantBase (http://www.emplantbase.org/ home.html) and Plantarium (https://www.plantarium. $\mathrm{ru} /$ ) were used.

All this information for each species is entered into the database (DB) Wild Relatives of Cultivated Plants of Russia (Informregister No. 0229905883). Such a DB is a multifunctional tool for further CWR analysis. The current version contains the nomenclature (scientific and Russian names of taxa, including nomenclature synonyms) and a basic description of CWR species that grow in Russia. General characterization includes the rank according to the degree of relationship with cultivated plants, distribution pattern (general, and more specific within Russia), most characteristic habitats, life form type, ways of utilization, and conservation criteria. The description of each species is illustrated by photographs of the plant taken in its natural environment, as well as by a map of the distribution area. All the information gathered in the information retrieval system (IRS) is necessarily supplied by links to the literature used. To facilitate the entry and formalization of the information entered into the database, the IRS is equipped with such reference sections as the "Administrative Division of Russia", "Nature Reserves", "Habitat Characterization", "Life Forms", "Conservation Criteria", and "Soil Characterization". Currently, the database contains information about 1701 CWR species from 49 families and 175 genera. Analysis of the collected data showed that the families most rich in CWR species are the Poaceae (491 spe- 

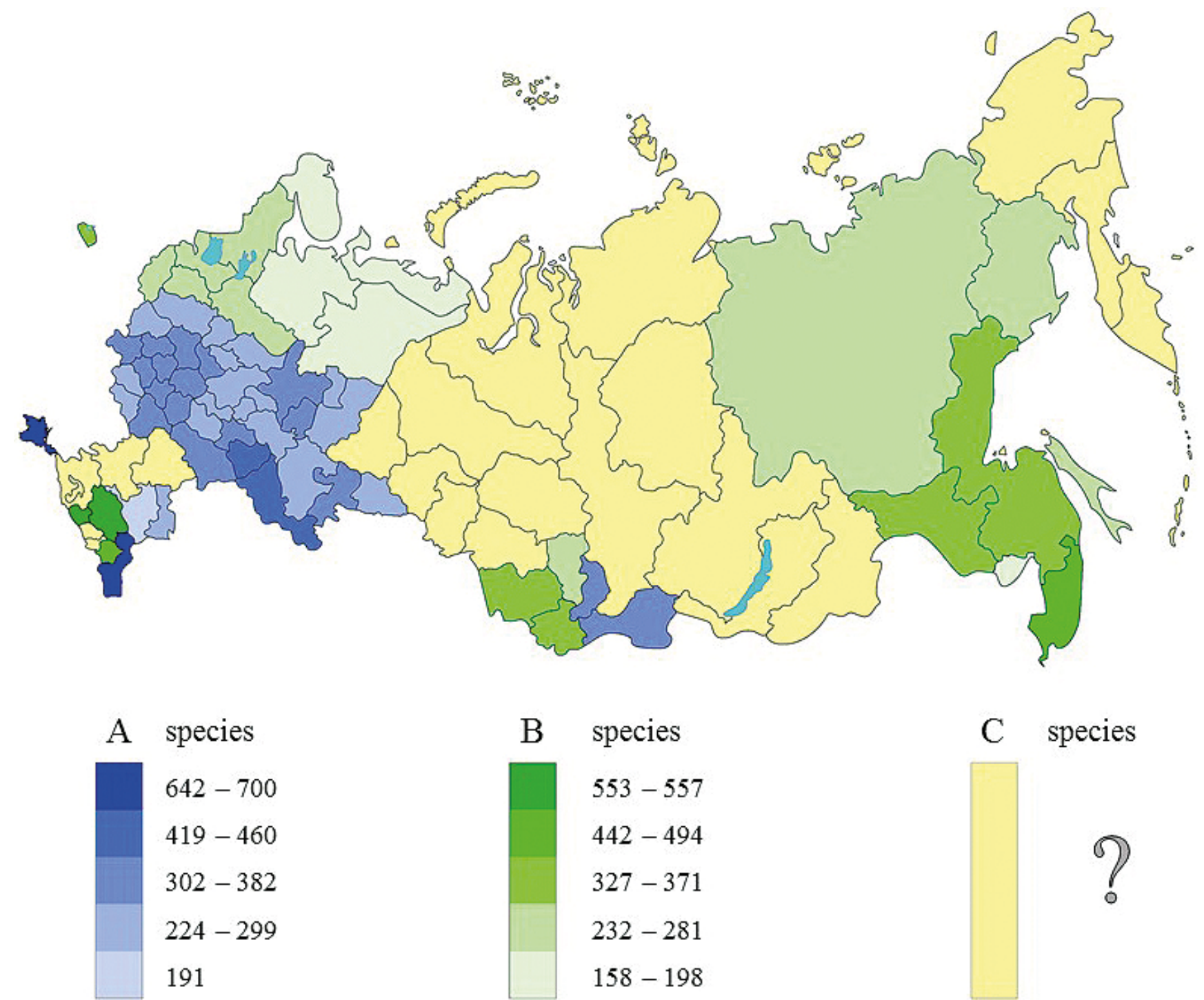

Fig. 1. Degree of knowledge on CWR diversity in administrative regions of Russia: A — Preliminary list of CWR composed; B - Inventory of CWR diversity completed, recommendations on its conservation issued; C - CWR diversity not yet inventoried.

cies), Fabaceae (273), Rosaceae (177) and Amaryllidaceae (106). The maximum number of CWR is contained by such genera as Allium (106 species), Poa (103), Festuca (82), Rosa (65), Vicia (61), and Lathyrus (62). From the results of the CWR species analysis according to the type of use, it follows that the undoubted leadership belongs to fodder plants with 398 species, followed by food (fruits, berries and vegetables) - 346 species.

Geographic analysis showed that CWR species are unevenly distributed across Russian regions. In floristic terms, the territory of the European part of Russia is very diverse and represents a conglomerate of floras of different genesis, therefore, the largest number of CWR species (868) grows in this territory. Most of them are widespread within the Holarctic floristic kingdom (Kamelin, 2017). Concerning their distribution within Russia, 152 CWR species are limited only to its European part, 18 of them being endemic to it (e.g., Agropyron tanaiticum Nevski, Agrostis korczaginii Senjan.-Korcz., Avena aemulans Nevski, Rosa microdenia Mironova, Lotus zhegulensis Klokov, etc.), and 13 subendemic ( $A g$ ropyron lavrenkoanum Prokudin, Agrostis salsa Korsh., Elymus uralensis (Nevski) Tzvel., Trifolium borysthenicum Gruner, Rosa grossheimii Chrshan., etc.). The Caucasus as a whole is one of the regions in Russia that is most rich in species, of which 766 are CWR species. The Russian Far East ranks third in terms of the number of CWR species (606). The flora of the Russian Far East is influenced by the East Asian center of speciation, therefore CWR diversity is very peculiar and contains a large number of species (223) that grow only in this territory. Eastern Siberia numbers at least 564 CWR species, while the smallest number of CWR is concentrated in Western Siberia (544).

Such geographic features of Russia as the large territory and location in several natural zones create another 
problem in studying CWR diversity. Given the size of this country and the difficulties of studying its entire floristic diversity, it was decided to continue inventorying the CWR diversity of Russia in administrative regions, territories and republics, and compose a complete annotated list of CWR of Russia by summarizing all the obtained data. This way, the diversity of wild relatives of cultivated plants has already been studied in detail in the Northwestern Federal District (Shipilina, 2016), the Vologda Province (Shipilina, 2018, 2019), the Republic of Bashkiria (Miftakhova et al., 2014), the Chechen Republic (Bagmet and Taysumov, 2018), the Amur Province (Talovina and Aistova, 2017), Primorsky Territory (Talovina and Aistova, 2018), the Magadan Province (Talovina and Aistova, 2019), Yakutia (Danilova et al, 2013), and the Kemerovo region (Kovrigina and Romanova, 2017). The degree of knowledge on CWR diversity in administrative regions of Russia is presented in a schematic map (Fig. 1).

An important stage in inventorying CWR diversity is the study of their distribution areas. According to R. V. Kamelin (2019), a distribution area of any species is a total, integrated spatial display of all the biological and ecological features inherent in a species that are revealed during the life of a species in a changing environment (both ecological and biotic) and, therefore, it is a reflection of the species' "stamina", or its tolerance (Kamelin, 2019). When working with wild relatives of cultivated plants, the distribution area should be studied thoroughly and consistently, starting with its modern outline, historical conditionality, and ending up with the character of localization of individual populations of the species. Modern technologies (geographic information systems, remote sensing methods) make it possible to manage large volumes of cartographic information and obtain relevant information on species distribution. In the framework of the project Agroecological Atlas of Russia and Neighboring Countries: Economically Significant Plants, Their Diseases, Pests and Weeds (Afonin et al., 2008), we started creating electronic maps of CWR distribution areas in Russia. These maps are used to analyze CWR distribution and ecology, to identify the places of concentration of the greatest CWR species diversity, to refine data on the priority taxa for conservation (narrowly localized endemics, disjuncted distribution areas, etc.) and to select places for the in situ conservation of their genetic diversity.

\section{Selection of priority CWR taxa for in situ conservation in Russia}

Obviously, it is impossible to effectively preserve the entire CWR diversity throughout Russia, so priorities should be identified. CWR species are unequal both in terms of rarity and vulnerability in their habitats, and in terms of the degree of demand by humans and economic significance. We have developed criteria on the basis of which priority CWR species can be selected for in situ conservation. There are two such criteria: (A) relationship and economic significance; and (B) rarity and vulnerability (Smekalova, 2011).

European researchers (Maxted et al., 2011; Fielder et al., 2015) consider the criterion of economic significance to be the most important, but as T. N. Smekalova rightly observes, “... if we do not conserve a species today, the future significance of its economic component will be lost" (Smekalova, 2011, p. 64). To identify priority species for conservation, we analyze each species from the general CWR list according to both criteria, consisting of separate indicators.

A. The criterion of relationship with cultivated species and economic significance consists of such indicators as:

- participation in the breeding process (existence of varieties; use in hybridization, as donors of useful traits, as rootstocks, etc.),

- the degree of use for economic purposes,

- systematic (taxonomic) closeness to the cultivated species.

As a result of the analysis according to this criterion, the revealed CWR diversity can be divided into five groups:

1) The species is cultivated, contains varieties, and is economically important (222 species).

2) The species participates in crosses and is used as a rootstock or source of genes (72 species).

3) The species is promising for utilization; closely related to the cultivated species (within one section or subgenus) (173 species).

4) Other useful species of the same genus (useful plants), objects of plant hunting or folk breeding (no varieties) (350 species).

5) All other species of the genus, the useful properties of which are still little studied (884 species). Thus, 294 species that belong to the first two ranking groups and are most actively used in breeding can be considered priority species according to criterion $\mathrm{A}$. These results show that only slightly more than $2 \%$ of the country's phytodiversity is intensively used in agricultural production in Russia. The species from the third and fourth groups can be potentially involved in economic activity.

B. The criterion of rarity and vulnerability. For most CWR species, there is no real threat of extinction in their habitats. However, some of them are included in the Red Book of Russia (Varlygina et al., 2008) and regional Red Books. Such species are subject to priority conservation in situ. The narrowly localized endemics of 
different regions and, in some cases, relics of different eras, as well as CWR species, which have a small part of their distribution area in the territory of Russia, should also be designated for priority CWR preservation.

Of the species listed in the Red Book of Russia, 49 are wild relatives of cultivated plants: 0 (Possibly Extinct) Anthyllis kuzenevae Juz.; 1 (Endangered) - Festuca bargusinensis Malyschev, Crambe cordifolia Stev., Vicia hololasia Woronow, Vicia tsydenii Malyschev, Papaver bracteatum Lindl.; 2 (Decreased in number) - Elytrigia stipifolia (Czern. ex Nevski) Nevski, Psathyrostachys daghestanica (Alexeenko) Nevski, P. rupestris (Alexeenko) Nevski Secale kuprijanovii Grossh., Corylus colurna L., Crambe koktebelica (Junge) N. Busch, Lepidium meyeri Claus, Lonicera tolmatchevii Pojark., Cicer minutum Boiss. et Hornem., Vavilovia formosa (Stev.) Fed., Thymus pulchellus C. A. Mey., Rheum compactum L., Prinsepia sinensis (Oliv.) Bean; 3 (Rare) - Armeniaca mandshurica (Maxim.) Skvortsov, Amygdalus pedunculata Pall., Juglans ailanthifolia Carr., Medicago cancellata Bieb., Lespedeza tomentosa (Thunb.) Maxim., Lathyrus venetus (Mill.) Wohlf., Pistacia mutica Fisch. et C.A. Mey., Allium gunibicum Miscz. ex Grossh., A. bellulum Prokh., etc.

The Red Books of the federal subjects of the Russian Federation (only the Red Books that comply with regulatory legal acts were taken into account) list $534 \mathrm{CWR}$ species $(31.4 \%)$. Most of the protected CWR species have the "3-Rare" status, that is, they are characterized by low abundance in nature, occur in a limited territory, or are sporadically spread over large areas, and special protective measures are necessary for their survival. These species include:

- narrowly localized endemics;

- species with a significant distribution area, within which they occur sporadically;

- species with a narrow ecological confinement associated with specific growing conditions;

- species with a significant common distribution area, but at the border of this area in Russia;

- species with a limited range, part of which is located in Russia.

However, there is a small number of taxa that are considered to have disappeared $\left(0^{*}\right)$ or probably disappeared (0), i.e. these are the previously known species which have not been found in the last 25-50 years. For example, these are Lotus angustissimus L. in the Republic of Bashkortostan, Rumex sanguineus L., Avena aemulans Nevski and Poa remota Forsell. in the Lipetsk Province, Oxycoccus microcarpus Rupr. in Mordovia, Rubus humilifolius C. A. Mey. in the Mari El Republic, and R.nessensis W. Hall in the Udmurt Republic.

Special measures are required to preserve gene pools of such CWR species as Avena aemulans and
A.volgensis (Vav.) Nevski, which are both specialized weeds in cultivated plant crops (in particular, of Volga emmer wheat) and the Volga endemics of Russia, which are disappearing as emmer wheat disappears as a crop. Gene pools of such CWR species should be preserved $e x$ situ and on farm.

When analyzing the diversity of wild relatives of cultivated plants in the Northwestern Region of Russia, L. Yu. Shipilina has developed a point system for selecting species that require priority in situ conservation and inclusion in the CWR red list $(2016,2019)$. However, the proposed technique has a number of weak points and requires refinement.

As a result, the conducted studies yielded a preliminary list of 340 CWR priority species for in situ conservation in Russia. The work is still underway, and the list can be either extended or shortened.

\section{Selection of conservation area}

As noted above, an important methodological approach for specifying the territories where priority species should be preserved is the construction and analysis of the distribution area maps using GIS technologies. By overlapping the distribution area maps for the taxa of priority for conservation, it becomes possible to identify locations of their maximum concentration, so-called hotspots. By overlaying the distribution area maps and soil-climatic maps of territories, it becomes possible to identify the factors that limit the distribution of individual taxa and populations.

It is impossible to maintain all priority species throughout the areas of natural distribution. The most realistic approach is to preserve these species within the existing network of specially protected natural areas (SPNA). It was V.V. Nikitin and O. N. Korovina (1973, 1980a) who drew attention to the role of nature reserves in the conservation of wild relatives of cultivated plants for the first time.

\section{Conservation of the diversity of wild relatives of cultivated plants in specially protected natural areas (SPNA) of Russia}

Within the Russian Federation, 19,717 specially protected areas of federal, regional and local significance have been organized. Based on the character of tasks, regime and status, the protected areas are distinguished as state nature reserves, including biosphere reserves; national parks; natural parks; state nature sanctuaries; natural monuments; arboreta and botanical gardens; and medical and recreational areas and resorts (http://oopt.aari. $\mathrm{ru} /$ ).

We have begun the work to identify CWR diversity growing in state nature reserves. In 2005, the book Wild 
Table 1. Distribution of CWR species by regions and nature reserves of Russia

\begin{tabular}{|c|c|c|c|c|c|}
\hline CWR species number & European Russia & Russian Caucasus & Western Siberia & Eastern Siberia & Far East \\
\hline In the region & 868 & 766 & 544 & 564 & 606 \\
\hline $\begin{array}{l}\text { In nature reserves (number, } \\
\text { and } \% \text { of the regional) }\end{array}$ & $\begin{array}{c}561 \\
64.6 \%\end{array}$ & $\begin{array}{c}387 \\
50.5 \%\end{array}$ & $\begin{array}{c}286 \\
52.6 \%\end{array}$ & $\begin{array}{c}391 \\
69.3 \%\end{array}$ & $\begin{array}{c}496 \\
81.8 \%\end{array}$ \\
\hline
\end{tabular}

Relatives of Cultivated Plants in Russian Nature Reserves. Cadastre. (Nukhimovskaya et al., 2005) was published, which contains data on CWR growing in 93 nature reserves (out of the 100 that existed at the end of 2004).

The cadastre included CWR species of only the first four ranking groups according to the degree of relationship with cultivated species and to the economic significance. Currently, 111 state nature reserves operate in Russia. It was established that 102 nature reserves contain 1363 CWR species from 148 genera and 39 families, that is, $80.1 \%$ of their total number. So far, floras of the Crimean nature reserves (Kazantip, Karadag, Yalta Mountain-Forest), as well as of several recently organized nature reserves, e.g., Vasyugansky, Vishersky, Kologrivsky Forest, Lebyazhyi islands, Erzi, and Yugansky, have not been analyzed. About $19.9 \%$ of the total CWR number (338 species) do not occur in any other reserve in Russia (at least, they have not been found to date). The species used in breeding (those from the first two ranking groups) total 219 species in nature reserves (12.9\% of the total CWR number). A total of 337 CWR species ( $19.8 \%$ of their total number) are protected in only one of Russia's nature reserves. A number of species have a small part of their distribution area in Russia, for example, Elytrigia elongata (Host) Nevski, Capparis herbaceae Willd., Cornus mas L., Ficus carica L., Malus orientalis Uglitzk., Mespilis germanica L., Pyrus salicifolia Pall., Trifolium fontanum Bobrov, Rheum tataricum L., Hordeum brachyanterum Nevski, Morus bombycis Koidz., therefore it is not surprising that they are registered in the flora of only one nature reserve. The species with a broad distribution area that occupy ruderal habitats or are invasive in many regions of Russia (e.g., Lolium multiflorum Lam., Phalaris canariensis L., Eruca sativa Mill., Lepidium sativum L., Sinapis alba L.) are also present on the floristic lists of individual nature reserves.

Some species, such as Actinidia giraldii Diels and Prunus ussuriensis Koval. et Kostina, have an unclear taxonomic status, as many authors do not consider them independent species, which also leads to the situation that they are registered in only one nature reserve. Most CWR species have extensive distribution areas and are found in many nature reserves, for example, Festuca rubra L. occurs in 79 reserves, Elytrigia repens (L.) Nevski in 76, Poa pratensis L. in 73, P. angustifolia L. and Bromopsis inermis L. in 62, and Alopecurus pratetsis L. in 60.
CWR diversity is most effectively conserved in the nature reserve network of the Russian Far East and Eastern Siberia $(81.8 \%$ and $69.3 \%$, respectively, relative to the total CWR numbers in the region), and the least in the reserves of the Russian Caucasus, despite the significant concentration of CWR species in this region (Table 1).

Six nature reserves of Russia contain the minimum number (from 1 to 20) of CWR species, that is, 3 species in Nurgush, 6 in Voroninsky, 7 in Daurskyi, 9 in Gydansky, 13 in Bolshoy Arkticheskyi, and 15 in Ust-Lenskyi. The nature reserves with the largest number of CWR species are located in the Russian Caucasus, of Southern Siberia, Primorsky Territory and the chernozem zone of the European part of Russia (Fig. 2).

The Red Book of Russia (2008) includes 23 CWR species growing in nature reserves: Allium pumilum Vved., A. regelianum, Asparagus brachyphyllus Turcz., Elytrigia stipifolia, Festuca sommieri Litard., Secale kuprijanovii, Pistacia mutica, Corylus colurna, Crambe koktebelica, Lonicera etrusca Santi, Lespedeza tomentosa (Thunb.) Maxim., Medicago cancellata, Hypericum montbretti Shach., Juglans ailanthifolia, Thymus cimicinus F. K. Blum ex Ledeb., Papaver lapponicum (Tolm.) Nordh., P. lisae N.Busch, Aconogonon amgense (V. Michaleva et Perfiljeva) Tzvelev, Rheum compactum, Armeniaca mandshurica, Prinsepia sinensis, Staphylea colchica Stev., Viburnum wrightii Miq.

A total of 26 CWR species included in the Red Book (2008) are not found within any of the nature reserves of Russia. These are mainly the species of the Russian Caucasus and the southeast of the European part of Russia, such as Allium grande, A.gunibicum, A.paradoxum, Psathyrostachys daghestanica, P. rupestris, Crithmum maritimum L., Crambe cordifolia, C.steveniana Rupr., Lepidium meyeri, Diospyros lotus, Cicer minutum, Lathyrus venetus, Vavilovia formosa, Vicia hololasia, Hyssopus cretaceus Dubj., Thymus pulchellus, Papaver bracteatum, Staphylea pinnata L. It can be assumed that the fate of the species growing in protected areas will be more prosperous than that of those beyond their boundaries. The areas of CWR concentration outside nature reserves can be considered as territories for the creation of microreserves and used for establishing new or expanding the existing protected areas. When developing principles for the formation of a promising system of terrestrial fed- 


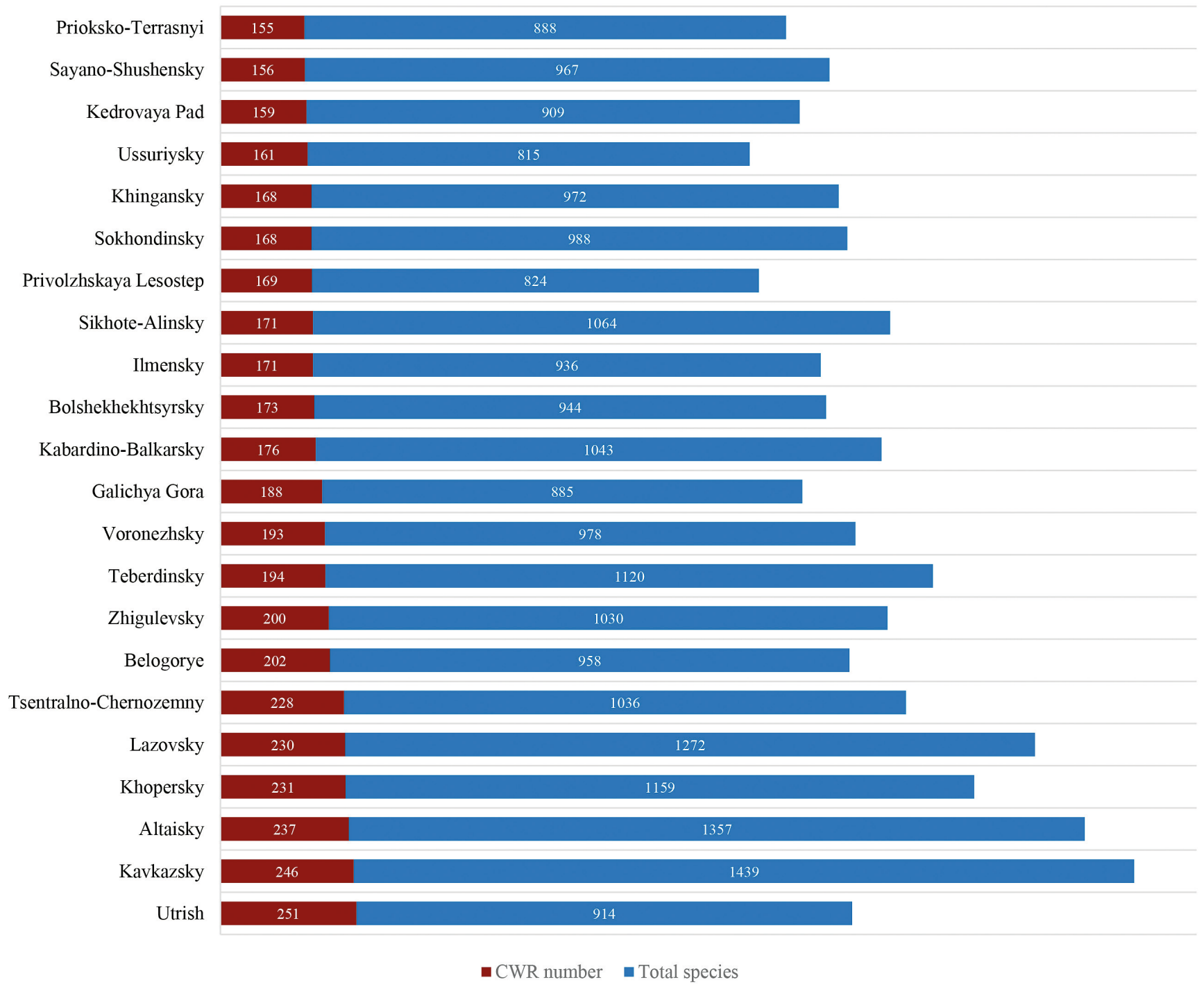

Fig. 2. Nature reserves with the largest number of CWR species.

eral specially protected areas in Russia, it was indicated that one of the provisions for organizing such areas is the presence of rare and unique plant communities with a high concentration of wild relatives of cultivated plants (Krever et al., 2009).

\section{Conclusion}

The study of the diversity of wild relatives of cultivated plants of Russia is still far from completion. Only the first phase of the inventory was carried out, which made it possible to compile a checklist of CWR in Russia, register their diversity within the state natural reserves and prepare a preliminary list of priority CWR species for conservation. Plant diversity has been analyzed in detail in only 23 federal subjects of the Russian Federation, for which recommendations concerning in situ conservation at the regional level have been issued. The methodological approaches of the currently developed domestic strategy for in situ conservation of CWR genetic diversity of Russia (Smekalova, 2011) regarding monitoring and management of various in situ conservation objects, are only declarative in nature. Nevertheless, the relevance of such studies is increasing with every year, since plant genetic resources seriously affect the well-being of each country and play a key role in ensuring not only food security, but also economic prosperity. Conservation of agrobiodiversity, a significant part of which are relatives of cultivated plants, is outgrowing the frames of a scientific problem and developing into a socio-economic, geopolitical, moral and ethical one, and today affects all countries of the world without exception (Alexanian, 2002). Many experts have come to the opinion that plant genetic resources are more important than arms for national security, and according to CIA experts, conflicts on this issue will occur more often (Weaver, 1987, cited from Alexanian, 2002), therefore the problems of plant genetic resources conservation should be tackled at the national level. 


\section{Acknowledgement}

This study is supported by VIR project No 0662-2019-0005.

\section{References}

Afonin, A. N., Greene, S. L., Dzyubenko, N. I., and Frolov, A. N. 2008. Interactive agricultural ecological atlas of Russia and neighboring countries. Economic plants and their diseases, pests and weeds [Online]. Available at: http:// www.agroatlas.ru

Alexanyan, S. M. 2002. Agrobiodiversity and geopolitics. SPb. VIR. 360 p. (In Russian)

Bagmet, L. V. and Taysumov, M. A. 2018. Crop wild relatives conservation in the Chechen Republic. Proceedings on Applied Botany, Genetics and Breeding 179(3):12-22. https:// doi.org/10.30901/2227-8834-2018-3-12-22 (In Russian)

Brezhnev, D. D. and Korovina, O. N. 1981. Wild congeners of cultivated plants in the flora of the USSR. 375 p. (In Russian)

Chukhina, I. G. 2001. Methodological aspects of the analysis of regional floras for plant genetic resources conservation (on the example of the flora of the Northeastern Altai). Scientific and Technical Bulletin of VIR 240:72-76. (In Russian)

Chukhina, I. G. 2007. Cultivated plants and their wild relatives (methods for the study and conservation of diversity). Barnaul. 40 p. (In Russian)

Convention on biological diversity (Rio de Janeiro, June 05, 1992). United Nations. 1992. Available at: https://www. un.org/ru/documents/decl_conv/conventions/pdf/biodiv.pdf

Danilova, N. S., Korobkova, T. S., and Semenova, V. V. 2013. Wild relatives of cultivated plants of Yakutia. Novosibirsk. 31 p. (In Russian)

European Plant Conservation Strategy. 2001. 47 p.

Fielder, H., Brotherton, P., Hosking, J., Hopkins, J.J., FordLloyd, B., and Maxted, N. 2015. Enhancing the conservation of crop wild relatives in England. PLOS ONE 10(6):e0130804. https://doi.org/10.1371/journal.pone.0130804

Gel'tman, D. V., Antonova, N. N., Byalt, V.V., Grabovskaya, A. E., et al. 1998. Flora of the vascular plants of the Russian Federation. Biology Bulletin 25(1):93-97. (In Russian)

Global Plan of Action for the Conservation and Sustainable Utilization of Plant Genetic Resources for Food and Agriculture and the Leipzig Declaration. 1996. Commission on Genetic Resources for Food and Agriculture Food and Agriculture Organization of the United Nations (FAO). 63 p. Available at: http://www.fao.org/pgrfa-gpaarchive/docs/gpa_en.pdf

Global Strategy for Plant Conservation. 2002. The sixth meeting of the Conference of the Parties to the Convention. (VI/9):160-173. Available at: https://www.cbd.int/decision/cop/default.shtml?id=7183

Godfray, H. C., Beddington, J. R., Crute, I. R., Haddad, L., Lawrence, D., Muir, J. F., et al. 2010. Food security: The challenge of feeding 9 billion people. Science 327(5967):812818. https://doi.org/10.1126/science.1185383

Harlan, J. R. and de Wet, J. M. J. 1971. Towards a rational classification of cultivated plants. Taxon 20:509-517. https:// doi.org/10.2307/1218252

International treaty on plant genetic resources for food and agriculture. 2001. Available at: http://www.fao.org/ plant-treaty/overview/texts-treaty/en/

Iriondo, J., Dulloo, M. E., Maxted, N. 2008. Conserving plant genetic diversity in protected areas: population management of crop wild relatives. CABI Publishing, Wallingford. 288 p. https://doi.org/10.1079/9781845932824.0000
Kamelin, R. V. 2002. The most important features of vascular plants and floristic zoning of Russia. Problems of Botany of South Siberia and Mongolia 1:36-41. (In Russian)

Kamelin, R. V. 2017. Flora of the Earth: floristic zoning of land. 128 p. (In Russian)

Kamelin, R. V. 2019. Geography of plants. 306 p. (In Russian)

Korovina, O. N. 1980a. Establishment of reserves and protected natural lands in the USSR - is the basis for conservation of populations of cultivated plants relatives. Bulletin of applied botany, genetics and plant breeding 68(3):145150. (In Russian)

Korovina, O. N. 1980b. The natural genetic diversity of wild relatives of cultivated plants in the flora of the USSR and its protection. 125 p. (In Russian)

Korovina, O. N. 1984. Using wild relatives of cultivated plants of the Central Asian gene center in plant industry. Bulletin of applied botany, genetics and plant breeding 88:114121. (In Russian)

Korovina, O. N. 1986. The natural genetic diversity of wild relatives of cultivated plants in the flora of the USSR and its protection (Annotated list). 126 p. (In Russian)

Kovrigina, L. N. and Romanova, N. G. 2017. Wild relatives of cultivated plants of the Kemerovo region flora. Problems of Botany of South Siberia and Mongolia 16:35-37. (In Russian)

Krever, V. G., Stishov, M. S., and Onufrenya, I. A. 2009. Specially protected natural territories of Russia: current status and development prospects. WWF России. 456 p. (In Russian)

Malyshev, L. I., Doronkin, V. M., Zuev, V. V., et al. 2012. Compendium of the flora of Asian Russia: vascular plants. Novosibirsk. 640 p. (In Russian)

Maxted, N, Ford-Lloyd, B. V., Kell, S. P., Iriondo, J., Dulloo, E., and Turok, J. 2008. Crop wild relative conservation and use. Wallingford: CABI Publishing. https://doi. org/10.1079/9781845930998.0000

Maxted, N., Dulloo, M.E., Ford-Lloyd, B. V., Frese, L., Iriondo, J.M., and Pinheiro de Carvalho, M.A.A. 2011. Agrobiodiversity conservation: securing the diversity of crop wild relatives and landraces. UK: Wallingford: CABI Publishing; 392 p. https://doi.org/10.1017/ S0014479712000919

Maxted, N., Ford-Lloyd, B. V., Jury, S. L., Kell, S. P., and Scholten, M. A. 2006. Towards a definition of a crop wild relative. Biodiversity and Conservation 15(8):2673-2685. https://doi.org/10.1007/s10531-005-5409-6

Maxted, N., Ford-Lloyd, B. V., and Hawkes, J. G. 2000. Complementary conservation strategies; pp.15-39. In: Maxted, N., Ford-Lloyd, B. V., and Hawkes, J. G. editors. Plant Genetic Conservation. Springer, Dordrech. https://doi. org/10.1007/978-94-009-1437-7_2

Maxted, N., Ford-Lloyd, B. V., and Hawkes, J. G. 1997. Plant genetic conservation: The in situ approach. London: Chapman \& Hall, 446 p. https://doi.org/10.1007/978-94-009-1437-7

Maxted, N. and Kell, S. P. 2009. Establishment of a network for the in situ conservation of crop wild relatives: status and needs. Commission on genetic resources for food and agriculture. Rome, Italy: Food and Agriculture Organization of the United Nations; 224 p. Available at: http:// www.fao.org/3/i1500e/i1500e18d.pdf

Maxted, N., Magos Brehm, J., and Kell, S. 2013. Resource book for the preparation of national conservation plans for crop wild relatives and landraces. University of Birmingham, UK. 463 p. Available at: http://www.fao.org/fileadmin/templates/agphome/documents/PGR/PubPGR/ResourceBook/TEXT_ALL_2511.pdf

Mayevsky, P. F. 2014. Flora of the Central Belt of the European part of Russia. Moscow. KMK Scientific Publications Partnership. 635 p. (In Russian) 
Miftakhova, S. R., Abramova, L. M., and Yamalov, S. M. 2014 Rare and vulnerable species of crop wild relatives in plant communities of the Republic of Bashkortostan. Bulletin of Udmurt University. Series Biology. Earth Sciences (4):12-17. (In Russian)

Nikitin, V.V. and Bondarenko (Korovina), O. N. 1973. Wild relatives of cultivated plants, their protection and role in breeding. Bulletin of applied botany, genetics and plant breeding 49(3):280-291. (In Russian)

Nikitin, V.V., and Bondarenko (Korovina), O. N. 1975. Wild relatives of cultivated plants and their distribution in the USSR (compendium). 70 p. (In Russian)

Nukhimovskaya, Y. D., Smekalova, T. N., and Chukhina, I. G. 2005. Crop wild relatives in the natural reserves of Russia. Cadastre. 85 p. (In Russian)

Popov, M. G. 1928-1929. Wild growing fruit trees and shrubs of Asia Media. Bulletin of applied botany, genetics and plant breeding 22(3):241-272. (In Russian)

Porter, J. R., Xie, L., Challinor, A. J., Cochrane, K., Howden, S. M., Iqbal, M. M., et al. 2014. Food security and food production systems; pp. 485-533. In: Field, C. B., Barros, V. R., Dokken, D. J., Mach, K. J., Mastrandrea, M. D., Bilir, T. E., et al., editors. Climate change 2014: Impacts, adaptation, and vulnerability. Part A: Global and sectoral aspects. Contribution of working group ii to the fifth assessment report of the intergovernmental panel on climate change. Cambridge, United Kingdom and New York, NY, USA: Cambridge University Press.

Second Global Plan of Action for Plant Genetic Resources for Food and Agriculture. 2011. Commission on Genetic Resources for Food and Agriculture Food and Agriculture Organization of the United Nations (FAO). 112 p. Available at: http://www.fao.org/3/a-i2624r.pdf

Shipilina, L. Yu. 2016. Catalog of world collection VIR. 832:101. (In Russian)

Shipilina, L. Yu. 2017. The question of the conservation of wild relatives of cultivated plants in the territory of Leningrad, Novgorod and Pskov regions. Proceedings on Applied Botany, Genetics and Breeding 178(4):22-28. https:// doi.org/10.30901/2227-8834-2017-4-22-28 (In Russian)

Shipilina, L. Yu. 2018. Crop wild relatives in Vologda province. Proceedings on Applied Botany, Genetics and Breeding 179(3):49-60. https://doi.org/10.30901/2227-8834-20183-49-59 (In Russian)

Shipilina, L. Yu. 2019. Crop wild relatives in Vologda province, recommended for in situ conservation. Vavilovia 2(1):1230. https://doi.org/10.30901/2658-3860-2019-1-12-30 (In Russian)

Sinskaya, E. N. 1928. The oleiferous plants and root crops of the family Cruciferae. Bulletin of applied botany, genetics and plant breeding 19(3):3-646. (In Russian)

Sinskaya, E. N. 1969. Historical geography of cultivated flora (at the dawn of agriculture). Leningrad. 480 p. (In Russian)

Smekalova, T. N. 2011. Modern methods and international experience in preserving the gene pool of wild plants (example of wild fruit). Almaty. 188 p. (In Russian)
Smekalova, T. N. and Chukhina, I. G. 2005. Crop wild relatives in Russian. Catalog of world collection VIR. 54 p. (In Russian)

Smekalova, T. N. and Chukhina, I. G. 2011. Crop wild relatives of European Russia for the problem of their in situ conservation. Belgorod State University Scientific Bulletin. Natural Sciences 9(15/1):38-43. (In Russian)

Smekalova, T. N. 2008. National crop wild relative. In situ conservation strategy for Russia. In: Maxted, N., FordLloyd, B. V., Kell, S. P., Iriondo, J., Dulloo, E., and Turok, J., editors. Crop wild relative conservation and use. Wallingford: CABI Publishing; pp.143-151. https://doi. org/10.1079/9781845930998.0143

Talovina, G. V. and Aistova, E. V. 2017. Inventarization and analyzis of the wild relatives of cultivated plants diversity of the Amur oblast. Proceedings on Applied Botany, Genetics and Breeding 178(2):16-24. https://doi. org/10.30901/2227-8834-2017-2-16-24 (In Russian)

Talovina, G. V. and Aistova, E. V. 2018. Crop wild relatives inventory and conservation in the Primorsky region of the Russian Federation. Proceedings on Applied Botany, Genetics and Breeding 179(3):39-48. https://doi. org/10.30901/2227-8834-2018-3-39-48 (In Russian)

Talovina, G. V. and Aistova, E. V. 2019. Crop wild relatives inventory and conservation in the Magadanskaya oblast' of the Russian Federation. Proceedings on Applied Botany, Genetics and Breeding 180(2):18-24. https://doi. org/10.30901/2227-8834-2019-2-18-24 (In Russian)

United Nations, Department of Economic and Social Affairs, Population Division (2019). World Population Prospects 2019: Highlights (ST/ESA/SER.A/423). Available at: https://population.un.org/wpp/Publications/Files/ WPP2019_Highlights.pdf

Varlygina, T. I., Kamelin, R. V., Kiseleva, K. V., et al. 2008. Red Book of the Russian Federation (plants and mushrooms). Moscow. KMK Scientific Publications Partnership. 855 p. (In Russian)

Vavilov, N. I. 1926. Studies on the origin of cultivated plants. Bulletin of applied botany and plant breeding 16(2):3-248. (In Russian)

Vavilov, N. I. 1931. Wild progenitors of the fruit trees of Turkestan and the Caucasus and the problem of the origin of fruit trees. pp. 271-286. In: Report and Proceedings of the IXth International horticultural congress, (London, august, 1930). London.

World development report 2008: Agriculture for Development. 2008. World Bank, Washington DC. 386 p. Available at: http://siteresources.worldbank.org/INTWDR2008/Resources/WDR_00_book.pdf

Zhukovsky, P. M. 1964. Cultivated plants and their congeners. 790 p. (In Russian)

Zhukovsky, P. M. 1968. New foci of origin, genetic centers of cultivated plant and narrowly endemic microcenters of related species. Botanicheskii Zhurnal 53(4):430-460. (In Russian)

Zhukovsky, P. M. 1970. World-wide genebank of plant for plant breeding (mega-centers and micro-centers). Leningrad. 88 p. (In Russian) 